\title{
Basic Ways and Means to Enhance the Functioning of the Regional Systems of Russian Athletes' Training
}

\author{
Olga Panova \\ Ph.D., Senior Lecturer, Department of Theory and Methods of Athletics, Volgograd State Physical Education Academy \\ Russia, Volgograd, 400005, Lenin pr., 78; Email: kole235@mail.ru
}

\section{Doi:10.5901/mjss.2015.v6n6s5p35}

\section{Abstract}

\begin{abstract}
The paper studies the efficiency of the regional systems of training athletes and developing the ways to increase their efficiency. Revealed is a backbone factor in the system of the long term preparation of elite athletes. It has been defined that the objective and subjective factors affect athletic performance. Based on the analysis and comparison of reference materials, as well as the results of interviews with a group of qualified experts, among a variety of such factors 25 key factors were singled out that have a priority impact on the potential of the regional systems of training athletes; based on these factors a unified model for evaluating the potential of regional systems of training athletes has been developed. Assessment of the potential of regional systems of training athletes of Volgograd Region, Stavropol Territory, Krasnodar Territory was conducted. The typical regional systems of training Russian athletes were singled out, their efficiency was compared. We carried out the analysis of the functional efficiency (impact) of most regional systems of Russian athletes' training, the in-depth study of the potential of some of them, as well as the best practices of the Volgograd regional system. Based on this analysis we defined the main directions of improving the typical regional system of training elite athletes today. 28 basic recommendations for improving the typical Russian regional system of training athletes were specified.
\end{abstract}

Keywords: athletics, regional system, efficiency.

\section{Introduction}

The present level of achievements in athletics requires the optimal organization of athletes' training, the search and implementation of ever more effective ways, means and methods of training work with regard to all stages of long-term exercise, updating non-training and non-competition factors of improving athletic performance.

Despite the importance and advisability of the centralized models of training the national team members, the basis of the Russian athletes' success in the international arena is definitely laid in its regions. At the same time, it is a wellknown fact that not all regions of the Russian Federation provide the quality replacement of teenage, junior, youth and main teams. That is why we cannot achieve a decisive advantage in world athletics championships and the Olympics, although we have a significant advantage over our major foreign rivals in the number of athletes with the motivation to high performance, the general skill level of coaching staff, productivity of the advanced teaching concepts developed by the domestic sports science. The effective regional athletes' preparation systems (RAPS) have not yet been established in most of the republics, territories and regions of Russia. Moreover, the knowledge and enthusiasm of some creative coaches working there cannot compensate for the lack of effective organizational and methodological foundation.

In this respect Volgograd region has steadily advanced to a leading position in recent years. Given the basic unit population size - the performances of local athletes at the previous five Olympics rank second to none in other Russian regions and can be compared to those of the athletes of the German Democratic Republic in their best times. However, the main contributing factors are still not clearly defined, and the system of training Volgograd athletes has not been subjected to a comprehensive analysis either in its existing form, or, far less, in the dynamics of its progress from the stage of ordinary efficiency where it was two or three decades ago.

Our goal is to develop and substantiate a package of useful and feasible (potentially realizable) recommendations on improving the organizational and methodological foundations for the typical modern regional system of long-term training of athletes in the Russian Federation. 


\section{Literature Review}

The analysis of special literature has shown that a backbone factor in the long-term preparation of elite athletes is the achievement of high performances at the major international competitions (World and European championships, Olympic Games).

Competitions in the Olympic sports are a pivot determining the organization and methods of training athletes for effective competitive activities. It is the competition that reveals the adequacy of the organizational and methodological foundations of training, the efficiency of the system of reserve selection and training, the coaching staff skill and the effectiveness of the specialist training system, the level of sports science, the efficacy of scientific- methodological and medical support, as well as some other key parameters (Platonov 1996 Kazik 2004).

Sport achievements are affected by the objective and subjective factors. Group one comprises the level of national income per capita, caloric intake, life expectancy, literacy rate, the proportion of urban population, population size. Group two should primarily include the overall level of the organization of sports and the Olympic preparation system in Russia, the level of scientific and methodological developments in the field of youth sport and elite sport, the organization of sports reserve preparation, training and professional development of coaches and sports officials (Novokreschenov, 2006).

The system of elite athletes' preparation is entirely based on the system of athletic reserve training, with the foundation of both being laid in Russian regions.

The most important role in elite athletes' preparation is assigned to the mechanisms of effective management of their long-term performance improvement.

The main components of the Russian regional system of elite athletes' preparation in modern conditions are:

- $\quad$ the aggregation of organizations directly involved in athletes' long-term training;

- the cohort of athletes involved in all stages of long-term training;

- material and technical basis for athletic activities;

- coaching staff and coaching schools;

- regional infrastructure for biomedical support of athletic training;

- $\quad$ financing sports training and sports activities;

- specialized regional managerial structure (Cherkashin 2000, Ozolin 2002).

It was found that the factors providing for the effective management of sports training system (including one at the regional level), comprise: an adequate regulatory support; a well-developed system of multi-level physical education and sports events; the effective use of the media; good physical infrastructure for training; sufficient financial support; the availability of a government managerial body in the sphere of physical education and sports; the target program of physical education and sports development; qualified management personnel in the profile government and municipal bodies; participation in the international sports activities; the qualitative information support of administrative activities; the account of geopolitical and cultural characteristics; the adequate cooperation of governmental and municipal authorities in the sphere of physical education and sports with community sports organizations and associations (Matveev 1995, Glad in 2002, Bauer 2004).

The effectiveness of the system of elite athletes' preparation is affected by a wide range of factors, each of which, apparently, has a different significance at various stages of long-term training.

Based on the analysis and comparison of literature sources, as well as on the results of interviews with a group of qualified experts, we singled out 25 basic factors out of many:

- the availability of the organizational structure (the network of Youth Sports School, Youth Sports School of Olympic Reserve, Olympic Reserve Academies, sports clubs, etc.) that is necessary for the successful functioning of the regional system of elite athletes' preparation;

- $\quad$ efficient management on the part of the All-Russia Athletics Federation;

- managerial activities of the regional athletics federation (or the governmental authority exercising its function on administration of physical education and sports in the subject of the Russian Federation);

- a rational regional competition schedule;

- the opportunity to participate in the away meets;

- an efficient system of coaching staff preparation;

- $\quad$ an efficient career development system for coaches;

- professional level of employed coaches;

- professional level of sports organization workers;

- $\quad$ the availability of the necessary physical infrastructure for training; 
- the availability of training facilities, implements, equipment;

- efficient moral incentives;

- decent material incentives for employees;

- research and methodical support of training;

- $\quad$ the use of modern training concepts, non-traditional means of training;

- the opportunity to organize and conduct training camps at a suitable time (including those in the midlands);

- efficient planning of sports training;

- efficient management of the training process;

- medical support of training process;

- $\quad$ the use of doping-free pharmacological substances of improving athletic performance;

- $\quad$ the application of remedial activities;

- the efficient system of posttraumatic rehabilitation;

- the efficient system of sports evaluation and selection;

- $\quad$ an individualized approach to athletes' preparation;

- adequate funding of training athletes (Platonov 1996, Sanderson 2003, Kazik 2004, Digel 2004, Krotee 2006, Panova 2014).

It is essential that the impact of each factor can be estimated. Prioritizing the above factors in relation to the regional system of elite Russian athletes' preparation and assessment of their actual manifestations at various stages of long-term training (which, in fact, is the characteristics of the system) is associated with the object and purpose of our study.

\section{Methodological Foundation of Research}

The methodological foundation of our research is a system-structural approach (Bertalanffy 1962, Blauberg, Yudin 1972, Afanasyev 1981, Nappelbaum 1980), and specifically in relation to the theoretical and applied modeling of innovative actions - in general (Drucker 1986, Rosnay 1979) and in the sphere of physical education and sports (Balsevich 2001, Balakhnichev 1996, Novikov 2003, Kazikov 2004, Kuzin 2000, Digel 2004, Glad 2002, Krotee 2006), as well as the key tenets of the theory of training management, formulated by the leading Russian experts as applied to elite (Matveev 1995, Verkhoshanskiy 1995, Platonov 1996, Shustin 2003) and young athletes' preparation (Filin 1980, Nabatnikova 1988, Nikitushkin 2003, Bauer 2004).

Methods: analysis and synthesis of research and methodological literature sources; study of the official documents and information materials published in special periodicals; educational observation; questionnaires and interviews with experts, expert assessment; methods of mathematical statistics; logical analysis, theoretical analysis and theoretical synthesis.

\section{Results}

\subsection{The study of the efficiency of the Volgograd athletes' training system.}

The main efficiency indicator of the system of elite athletes' preparation is the top athletes' performance in major international competitions. Four Volgograd athletes participated in 2004 World Indoor Championships in Athletics (long jump, triple jump, pole vault, high jump); they won five medals with four golds among them. Four young Volgograd athletes qualified for the Russian team to participate in 2004 World Junior Championships in Athletics in summer of the same year and won 2 golds and 1 silver (triple jump, javelin, decathlon). Finally, jumper athletes Ye. Isinbayeva, T. Lebedeva and Ye. Slesarenko with their triumphant performances at the Athens Olympics won half (3 of 6) golds and 1 bronze for the Russian athletics. Based on their performances in the Olympic season these athletes confidently took the first three positions in the official women's rating list of the International Association of Athletics Federations (IAAF). The three consecutive summer and winter competition seasons that elapsed after the Olympic Games in Athens, also witnessed the excellence of the above athletes in their disciplines. At the World Championships in Athletics, held in August 2007 in Osaka (Japan), Volgograd athletes T . Lebedeva and Ye. Isinbaeva once again won 3 medals, 2 of them golds. T. Lebedeva was again awarded the title of the best Russian female athlete of the year. Later, at the 2008 and 2012 Olympics, Volgograd athletes did not remain without medals either, with Ye. Isinbaeva (Beijing, 2008), and Yu.Zarudneva (Zaripova) (London, 2012) becoming Olympic champions. Prize winners were T. Lebedeva (silver and bronze) in Beijing, and Ye. Isinbayeva (bronze) and A.Krivoshapka (silver) in London. 
Over the entire course of Volgograd athletes' performances at the Olympic Games, 28 athletes participated in the Olympics 43 times winning 13 medals, with 7 of them being golds.

\subsection{Development of the algorithm of evaluating the potential of a regional athletes' training system}

The system of elite athletes' preparation is entirely based on the training of athletic reserve, integrating it into itself as a subsystem. The end result of the system's work depends on the efficiency of each unit and its elements. To evaluate the work of the regional athletes' training system we have developed a unified model for evaluating the potential of such training systems.

Based on interviews with competent experts and the analysis of special literature we singled out 25 major factors that have a significant impact on the potential (potential efficiency) of functioning of the regional athletes' preparation system (RAPS).

Next, a group of qualified experts at our request filled out a special table - the so called matrix of pairwise comparisons, in which the compared objects (factors) are fixed twice - in rows and columns. At that, a more significant factor in the compared pairs was estimated with 1 point, while the less significant - with 0 points. Based on the examination results the assessment average revealed the importance of different factors:

a) in the regional system of training young athletes at the stages of preliminary training and initial specialization;

b) in the system of training young promising athletes at the stage of advanced training and sports perfection;

c) in the system of elite athletes' preparation. (Table 1).

Obtaining weighted estimates of the significance of the major factors influencing the potential RAPS efficiency in relation to different levels of athletes' qualification and age, allows to enter the unified model of assessing the potential of the system prevailing in a particular region of Russia.

We propose the following action sequence.

1. Qualified experts complete a questionnaire, which lists 25 major factors that affect the potential RAPS efficiency in relation to the athletes' particular qualification and age level. The real action (manifestation) of each factor is estimated by experts on a scale of 0 to 10 points.

2. The average expert estimates are multiplied by the factor weights (load factor) obtained previously, and all indicators are added.

Table 1. Expert assessments of importance (weights) of individual factors at different stages of long-term athletes' preparation

\begin{tabular}{|c|c|c|c|c|}
\hline \multirow{2}{*}{ № } & \multirow{2}{*}{ Factors } & \multicolumn{3}{|c|}{ Stages of long-term training } \\
\hline & & $\mathrm{A}$ & B & C \\
\hline 1 & $\begin{array}{l}\text { Availability of the organizational structure (the network of Youth Sports School, Youth Sports School } \\
\text { of Olympic Reserve, Olympic Reserve Academies, sports clubs, etc.) }\end{array}$ & 0,9583 & 0,9167 & 0,7500 \\
\hline 2 & Efficient training of coaching staff & 0,9167 & 0,6667 & 0,8333 \\
\hline 3 & Professional level of coaches & 0,9167 & 0,9583 & 1,0000 \\
\hline 4 & Efficient system of sports evaluation and selection & 0,8750 & 0,4583 & 0,0833 \\
\hline 5 & Availability of the necessary physical infrastructure & 0,7917 & 0,8333 & 0,8750 \\
\hline 6 & Level of material incentives for employees & 0,7917 & 0,8333 & 0,7500 \\
\hline 7 & Medical support of training & 0,7500 & 0,6667 & 0,6667 \\
\hline 8 & Efficient career development system for employees & 0,7083 & 0,3750 & 0,5417 \\
\hline 9 & Availability of training facilities, implements, equipment & 0,6250 & 0,8333 & 0,5417 \\
\hline 10 & Research and methodological support of training & 0,5000 & 0,5833 & 0,3750 \\
\hline 11 & A rational regional competition schedule & 0,4583 & 0,5000 & 0,1250 \\
\hline 12 & Professional level of sports organization workers & 0,4583 & 0,2083 & 0,2083 \\
\hline 13 & Efficient moral incentives for employees & 0,4583 & 0,0417 & 0,0000 \\
\hline 14 & Managerial role of the regional athletics federation & 0,4167 & 0,2500 & 0,2083 \\
\hline 15 & Efficient planning of sports training & 0,4167 & 0,5833 & 0,6667 \\
\hline 16 & Efficient management of the training process & 0,4167 & 0,6250 & 0,6250 \\
\hline 17 & Adequate funding of athletes' preparation & 0,4167 & 0,5000 & 0,7500 \\
\hline 18 & Opportunity to participate in the away meets & 0,3750 & 0,4167 & 0,6250 \\
\hline 19 & Individualized approach to athletes' preparation & 0,3750 & 0,5000 & 0,7083 \\
\hline 20 & Efficient management on the part of All-Russia Athletics Federation & 0,2500 & 0,0833 & 0,2083 \\
\hline 21 & Use of modern training concepts, non-traditional means of training & 0,2500 & 0,2917 & 0,2083 \\
\hline 22 & Opportunity to organize and conduct training camps at a suitable time & 0,1667 & 0,4167 & 0,5833 \\
\hline
\end{tabular}




\begin{tabular}{|c|c|c|c|c|}
\hline 24 & Application of remedial activities & 0,1667 & 0,5000 & 0,5833 \\
\hline 24 & Use of doping-free substances of improving athletic performance & 0,0417 & 0,1667 & 0,2500 \\
\hline 25 & Efficient system of posttraumatic rehabilitation & 0,0000 & 0,0417 & 0,2917 \\
\hline & Consistency of experts' assessment : $\mathrm{W}=$ & 0,877 & 0,819 & 0,859 \\
\hline & Confidence level: $p<$ & 0,01 & 0,01 & 0,01 \\
\hline
\end{tabular}

Note: A - stages of preliminary preparation and initial specialization; B - the stage of advanced training and sports perfection; $\mathrm{C}$ - the stage of elite sports mastery.

According to calculations, the maximum amount of points, which characterizes the "ideal" functioning of RAPS with reference to the stages of preliminary training and initial specialization, will be equal to 125 , with reference to the stage of advanced training and sports perfection - 122.5, and with regard to adult elite athletes' preparation - 124 6. It is therefore proposed to consider the RAPS that "scored" from 125 to 100 points, to be highly advanced; from 99 to 75 points promising; 74 points or less - in first priority need to be modernized.

Using a standardized assessment model it is possible to reliably characterize the potential efficiency of the athletes' training system, prevailing in a particular region of Russia. To do this, in each case, it is necessary to form a group of qualified experts, independent in their judgments, to conduct their briefing (including the subsequent enhancement of assessment consistency) and the actual process of questioning. After processing the questionnaire data we obtain the required evaluation of the potential efficiency of a particular RAPS.

Judging by the sum of relevant indicators in relation to elite athletes' preparation, the Volgograd RAPS "scores" 109.38 points, and it can be characterized as highly advanced. In regard to working with athletic reserve at the stages of preliminary training and initial specialization, as well as on the stages of advanced training and perfection, the local RAPS can be characterized as promising (75.34 points and 86.23 points respectively).

Using the technology developed by us, we evaluated the potential of two typical RAPS - in Stavropol and Krasnodar regions. On the sum of relevant indicators in relation to elite athletes' preparation the RAPS in Stavropol Territory "scores" 62.65 points and can be classified as one in priority need of modernization. A similar system in Krasnodar Territory "scores", in this case, 78.93 points and is characterized as promising. With regard to the organization of young athletes' training at the stages of preliminary training and initial specialization the integral indicator of the RAPS in Stavropol Territory is $\mathbf{5 3 . 9 4}$ points, which puts it in this case in the category of priority need of modernization. The RAPS of Krasnodar Territory "scores" 65.5 points here and is also characterized as being in priority need of modernization. With regard to the preparation of promising young athletes at the stage of advanced training and sports perfection the RAPS of Stavropol Territory "scores" 53.66 points and can be characterized as being in priority need of modernization, as well as the RAPS of Krasnodar Territory with its 65.5 points.

\subsection{The main ways of increasing the efficiency of regional athletes' training systems.}

Since the efficiency of the regional athletes' preparation systems (RAPS) is best characterized by qualifying to the national teams and the performance level of top athletes, we compared the representation in the lists of national teams (absolute measure is the number of people, relative one is the number of people converted to the urban population of the Federation subject), and then analyzed the ranking of national team members in the current lists of the world's elite athletes in particular competitive disciplines. This helped us rank the RAPS with highlighting more and less effective ones, and divide them into "typical" and "atypical". Based on the analysis of the Volgograd RAPS, a modern leader among its own kind, in the dynamics of its formation over 30-40 years, and the Stavropol and Krasnodar RAPS as its less efficient counterparts, we developed recommendations for improving the organization of training athletes in traditionally "athletic" Russian regions.

We specified 28 ways (basic recommendations) of improving the typical Russian RAPS. All of them were subject to examination in the course of a further survey of experts. The respondent group (28 pers.) included research and teaching staff of specialized athletic departments of universities (8 pers.), coaches (12 pers.), the workers of local Athletics Federations or government agencies performing their functions of managing physical education and sports in their respective subjects of Russian Federation (8 pers.).

Experts were asked to individually express their attitude to each of the measures offered, taking into account, in particular, the criteria of usefulness and feasibility (potential realizability). We provided for the following alternative answers: "I consider it expedient"; "I do not consider it expedient"; "It is difficult to estimate."

Before receiving the questionnaire checklist each expert had the opportunity to review the main results obtained in the previous stages of our study (first of all, with the collected statistics and commentaries on them). 
The survey summary in regard to the specified measures is as follows (the number of "pro", "con" and " difficult to estimate" votes are in parentheses).

Ways to improve the efficiency of a typical Russian RAPS:

1. Strengthening the inter-institutional coordination of the activities of sports clubs, Youth Sports Schools, Youth Sports Schools of Olympic Reserve, Olympic Reserve Academies, Sports Schools of Top Sportsmanship (22, $4,2)$.

2. Forming up an integral system of sports organizations that can provide for the real long-term continuity of talented athletes' unforced training $(22,1,5)$.

3. Improving the availability of properly equipped training facilities, modern types of implements and equipment $(23,1,4)$.

4. Assistance to physical education and sport societies and promoting the implementation of their statutory tasks $(19,5,4)$.

5. Strengthening the governing bodies of Athletics Federations by means of prioritized involvement of experts in the field of sports management, organization and methods of long-term elite athletes' preparation, while reducing the number of enthusiastic amateurs $(17,9,2)$.

6. The organization of regional workshops on athletics management with the participation of leading experts and mass media coverage $(20,3,5)$.

7. Allocation of additional funds from the regional budgets for the construction of the specialized athletic arenas meeting the all-Russian standards $(22,2,4)$.

8. Raising funds from sponsorship and other sources for the renovation of existing summer and suburban training bases $(25,3,0)$.

9. Increasing salaries of coaches at the expense of local budgets, the funds of the founders of sports schools and sports clubs, internal funds from extra-budgetary activities of sports organizations $(25,2,1)$.

10. Attracting sponsorship of local commercial structures for improving the material incentives of the coaches' work $(23,3,2)$.

11. Conducting regular competitions among coaches, the winners being awarded the "Coach of the Year" honorary title, supported by one-off material incentives $(15,7,6)$.

12. Establishing additional scholarships for promising athletes $(19,7,2)$.

13. Attracting the sponsor funds of the local commercial structures for raising prize funds in local competitions (23, 1, 4).

14. The timely involvement of professional managers in the work with talented young athletes, including their potential joining the workforce in sports organizations $(17,8,3)$.

15. Conducting annual regional competitions, with the winners being awarded the "Athlete of the Year" honorary title, supported by one-off material incentives $(17,7,4)$.

16. Enhancing the role of the most experienced and qualified coaches involved in the initial athlete recruitment, its time optimization, ensuring its real multistage character and the use of research-based technologies in sports selection $(24,1,3)$.

17. Schedule compression of children and youth sports events at the local level, ensuring the adequate continuity of competitions of various ranks and their pronounced orientation at promoting athletics among school students $(23,2,3)$.

18. Updating the work programs in the academic disciplines of profession-oriented departments at sports institutions of higher education, the involvement of expert coaches in student teaching, enhancing practice orientation of the educational process, increasing the admission of student-athletes to the professional master's educational program of "Sport and the athletes' training system" $(24,2,2)$.

19. Restoration of the earlier career development system on the basis of profession-oriented departments at sports institutions of higher education $(21,4,3)$.

20. Goal-oriented search, analysis, synthesis and targeted dissemination of information on innovative technologies in the training methods, means and methods of recovery, doping-free pharmacological substances $(24,1,3)$.

21. Participation in the IAAF international programs for training and certification of coaches $(20,1,7)$.

22. Conducting joint training camps with the participation of leading coaches-experts in teaching methodology (22, $3,3)$.

23. Upgrading the equipment for medical exercise dispensaries for effective rehabilitation and prevention of diseases in athletes $(21,3,4)$. 
24. Involvement of the region's leading physicians in counselling coaches and athletes $(21,2,5)$.

25. Practical implementation of the methods of applying doping-free substances to enhance athletic performance and optimize the recovery processes $(21,2,5)$.

26. Setting up the branches of anti-doping service on the basis of medical exercise dispensaries $(18,5,5)$.

27. The establishment of specialized structures responsible for physiological and pharmacological control and biochemical support of the training process $(21,1,6)$.

28. Promoting the rational discipline orientation of coaches and sports schools in general, at athletic disciplines which are objectively most "competitive" for the Russian athletes in the international arena $(19,7,2)$.

\section{Conclusion}

Based on the analysis of the functional efficiency (impact) of most regional systems of Russian athletes' training, the indepth study of the potential of some of them, as well as the best practices of the Volgograd regional system. we outlined the main directions of improving the typical regional system of training elite athletes in modern conditions

In our opinion, the complex of recommendations, developed by us, on the modernization of typical regional system of Russian athletes' preparation will allow to improve its productivity. In any case, the external experts agreed with that. Furthermore, the composite ratings of each of the separate proposed measure were obtained. In cases where experts were wary of positive assessments they mainly alleged their doubt in feasibility of the recommendations in the current conditions of their region, rather than doubt in their usefulness.

The results of the study, the collected statistical materials can be used primarily to improve the regional policy of the All-Russia Athletics Federation, as well as in management of Athletics Federations and territorial management in the sphere of physical culture and sports in the Russian regions.

We believe that the approach used in the study, can be transferred to the organization of similar studies on the material of other sports. Despite the somewhat general character of the recommendations produced, they allow specifying a rational policy in the development of sports at the regional level, and this is currently more important than another portion of the restricted methodological recommendations.

\section{References}

Afanasev, V.G. (1981) Odschestvo: sistemnost, poznanie i upravlenie. M. Politizdat [Afanasyev, V.G. (1981) Company: consistency, knowledge and management. Moscow. Politizdat].

Balakhnichev, V.V. (1996) K probleme celevogo programmirovaniya gosudarstvennoj podderzhki razvitiya legkoj atletiki v Rossii do 2004 goda. Teoriya i praktika- fizicheskoj kultury, 6, 15-17 [Balahnichev, V.V. (1996) On the problem of the target program of state support for the development of athletics in Russia until 2004. Theory and Practice of Physical Culture, 6, 15-17].

Balsevich, V.K. (2001) Kontury novoj strategii podgotovki sportsmenov olimpijskogo klassa. Teoriya i praktika fizicheskoj kultury, 4, 9-10 [Balsevich, V.K. (2001) The contours of a new strategy for the preparation of athletes of Olympic class. Theory and Practice of Physical Culture, 4, 9-10].

Bauehr, V.G. (2004) Sovremennaya sistema podgotovki sportivnogo rezerva Rossii i puti ego sovershenstvovaniya. Sport, ekonomika, pravo, upravlenie, 3, 12-15 [Bauer, V.G. (2004) Modern system of preparation of sports reserve of Russia and the ways of its perfection. Sports: economics, law, management, 3, 12-15].

Blauberg, I.V., Yudin, B.G. (1972) Ponyatie i ego rol v nauchnom poznanii, M. [Blauberg, I.V, Yudin, B.G. (1972) The concept of integrity and its role in scientific knowledge. Moscow]

Cherkashin, V.P. (2000) Individualizaciya trenirovochnogo processa yunykh sportsmenov v skorostno silovykh vidakh legkoj atletiki. Volgograd. VGAFK [Cherkashin, V.P. (2000) Individualization of the training process of young athletes in the speed-strength kinds of athletics. Volgograd. VGAFK].

Digel, H. (2004) Sport and television - trends and problems of a lucrative relationship. New Studies in Athletics, 2, 17-27.

Drucker, P.F. (1986) Innovation and entreprenership: Practice and principles. London. Pan Books

Filin, V.P., Fomin, N.A. (1980) Osnovy yunosheskogo sporta. M. Fizkultura i sport [Filin, V.P., Fomin, N.A. (1980) Fundamentals of youth sports. Moscow. Physical Training and Sports].

Glad, B. (2002) Successful athletic in a changing society (Seminar report). New Studies in Athletics. 2. 70.

Kazikov, I.B. (2004) Sovremennaya Sistema podgotovki rossijskikh sportsmenov k uchastiyu v igrakh olimpiad. M. Fizkultura i sport [Kazikov, I.B. (2004) The modern system of preparing Russian athletes for the Games of the Olympiad. Moscow. Physical Culture and Sports].

Krotee, M.L. (2006) Management of Physical Education and Sport. Social Sciences. Languages.

Kuzin, V.V. (2000) Optimizaciya sistemy upravleniy otraslyu fizicheskaya kulturi i sport v Rossii v rynochnykh usloviyakh. Teoriya i praktika- fizicheskoj kultury, 6, 56-58 [Kuzin, V.V. (2000) Optimization of the management of the sector "physical culture and sport" in Russia in market conditions. Theory and Practice of Physical Culture, 6, 56-58]. 
L. von Bertalanffy (1962) General System Theory-A Critical Review, «General Systems», vol. 7, 1-20.

Matveev, L.P. (1995) Zametki po povodu nekotorykh novacij vo vzglyadakh na teoriyu sportivnoj trenirovki Teoriya i praktika fizicheskoj kultury, 12, 49-52 [Matveev, L.P. (1995) Notes concerning some innovations in the views on the theory of sports training. Theory and Practice of Physical Culture, 12, 49-52].

Nabatnikova, M.Y. (1988) Osnovnye napravleniya nauchnykh issledovanij $v$ yunosheskom sporte (sostoyanie I perspektivy) M. Fizkultura i sport [Nabatnikova, M.Y. (1988) The main directions of research in youth sports (state and prospects) Moscow. Physical Training and Sports].

Nappelbaum, E.L. (1980) sistemnyj analiz kak programma nauchnogo issledovaniya. Sistemnye issledovaniya Metodologicheskie problem. M. pp. 80-92 [Nappelbaum, E.L. (1980) System analysis as a program of scientific research. System Research. Methodological problems. Moscow pp. 80-92].

Nikitushkin, V.G. (2003) Formirovanie programmno normativnogo obespecheniya sportivnykh shkol po olimpijskim vidam sporta. Teoriya i praktika fizicheskoj kultury, 6, 35-37 [Nikitushkin, V.G. (2003) Development of software and regulatory support of sports schools of Olympic sports. Theory and Practice of Physical Culture, 6, 35-37].

Novikov, A.A. (2003) Sistema podgotovki sportsmenov vysokoj kvalifikacii. Teoriya i praktika fizicheskoj kultury, 6, 38 [Novikov, A.A. (2003) The system of training highly skilled athletes. Theory and Practice of Physical Culture, 6, 38].

Novokreschenov, V.V. (2006) Vzaimodejstvie storon v upravlenii regionalnoj sistemoj fizicheskoj kulturoy i sporta. Izhevsk. IZHGTU [Novokreschenov, V.V. (2006) Interaction of the parties in the management of a regional system of physical culture and sport. Izhevsk. Izhevsk State Technical University].

Ozolin, N.G. (2002) Nastolnaya kniga trenera: Nauka pobezhdat. M. AST [Ozolin, N.G. (2002) Coach's Handbook: The Science of Winning. Moscow. AST].

Panova, O.S. (2014) Features a capacity assessment of system of training athletes the regional. Austrian Journal of Humanities and Social Sciences. Scientific journal, 6-7, 126-132.

Platonov, V.N. (1996) El entrenamiento deportivo. Barselona. Paidotribo.

Rosnay, J. (1979) The Macroscope: A New World Scientific System. NY.: Harper \& Row Publishers Inc.

Sanderson, L. (2003) Factors in the design and implementation of programs that will attract, recruit, retain and develop young athletes. New Studies in Athletics, 3, 27-34.

Shustin, B.N. (2003) Konceptualnye osnovy podgotovki sbornoj komandy Rossii k Olimpijskim igram. Teoriya i praktika fizicheskoj kultury, 6, 28-31 [Shustin, B.N. (2003) Conceptual Framework The Russian national team for the Olympic Games. Theory and Practice of Physical Culture, 6, 28-31].

Verkhoshanskij, Yu.V. (1988) Osnovy specialnoj fizicheskoj podgotovki sportsmenov. M. Fizkultura i sport [Verkhoshansky, Yu.V (1988) Based on special physical training of athletes. Moscow. Physical Training and Sports]. 